\title{
Methanogenium frittonii Harris et al. 1996 is a later synonym of Methanoculleus thermophilus (Rivard and Smith 1982) Maestrojuán et al. 1990
}

\author{
Correspondence \\ Stefan Spring \\ ssp@dsmz.de
}

\author{
Stefan Spring, Peter Schumann and Cathrin Spröer \\ DSMZ - Deutsche Sammlung von Mikroorganismen und Zellkulturen, Mascheroder Weg 1b, \\ D-38124 Braunschweig, Germany
}

\begin{abstract}
The $16 \mathrm{~S}$ rRNA gene sequence of [Methanogenium] frittonii DSM $2832^{\top}$ was determined and was found to be $99.9 \%$ similar to the sequence of Methanoculleus thermophilus DSM $2373^{\top}$. DNA-DNA hybridizations between both strains revealed $86 \%$ DNA-DNA binding, indicating that both strains belong to the same species. The determination of the DNA G+C content of both type strains, DSM $2832^{\top}$ and DSM $2373^{\top}$, revealed values of $56 \cdot 1$ and $59 \cdot 1 \mathrm{~mol} \%$, respectively. Based on the phenotypic and genotypic characteristics, it is proposed to unite the species [Methanogenium] frittonii and Methanoculleus thermophilus under the name Methanoculleus thermophilus, which is the earlier synonym and hence has priority. Emended descriptions of the species Methanoculleus thermophilus and the genus Methanogenium are also given.
\end{abstract}

The genera Methanogenium and Methanoculleus are phylogenetically related within the family Methanomicrobiaceae, which represent methanogens of highly irregular coccoid shape. The genus Methanogenium currently comprises five species with validly published names: Methanogenium cariaci, Methanogenium frigidum, [Methanogenium] frittonii, Methanogenium marinum and Methanogenium organophilum. Previously, the species [Methanogenium] bourgense, [Methanogenium] marisnigri, [Methanogenium] olentangyi and [Methanogenium] thermophilicum were transferred to the genus Methanoculleus by Maestrojuán et al. (1990). Later, Asakawa \& Nagaoka (2003) united Methanoculleus bourgensis, Methanoculleus olentangyi and Methanoculleus oldenburgensis in one species under the name Methanoculleus bourgensis. All described species of the genus Methanogenium, with the exception of [Methanogenium] frittonii, are psychrophilic to mesophilic and require acetate for growth. In contrast, the original description of [Methanogenium] frittonii by Harris et al. (1984) reports that this species is thermophilic and does not require acetate as a carbon source for growth. However, because of the lack of a 16S rRNA gene sequence, the phylogenetic relationship of [Methanogenium] frittonii to other members of the genus Methanogenium remained unclear. To clarify the taxonomic position of [Methanogenium] frittonii, we determined the almost complete $16 \mathrm{~S}$ rRNA gene sequence of the type strain DSM $2832^{\mathrm{T}}$.

Published online ahead of print on 9 December 2004 as DOI 10.1099/ ijs.0.63607-0.

The GenBank/EMBL/DDBJ accession number for the 16S rRNA gene sequence of strain DSM $2832^{\top}$ is AJ862839.
The strains [Methanogenium] frittonii DSM $2832^{\mathrm{T}}$ and Methanoculleus thermophilus DSM $2373^{\mathrm{T}}$ were grown under the conditions indicated in the DSMZ catalogue of strains (www.dsmz.de). For the isolation of DNA, each strain was cultured in about $10 \mathrm{l}$ of the respective DSMZ medium. After incubation for $48 \mathrm{~h}$ at $55^{\circ} \mathrm{C}$, cells were harvested by centrifugation. It turned out that both strains were very sensitive to lysis during resuspension of the cell pellet, which was done under oxic conditions. However, the loss of DNA could be efficiently prevented by resuspending the pellet in $80 \%(\mathrm{v} / \mathrm{v}) 2$-propanol (aqueous solution), which stabilized the nucleic acids.

Genomic DNA extraction and amplification of the $16 \mathrm{~S}$ rRNA gene of strain DSM $2832^{\mathrm{T}}$ was carried out as reported by Rainey et al. (1996). Purified PCR products were sequenced with the $\mathrm{CEQ}^{\mathrm{TM}}$ DTCS Quick Start kit (Beckman Coulter), as described in the manufacturer's protocol. The $\mathrm{CEQ}^{\mathrm{TM}} 8000$ Genetic Analysis System was used for the electrophoresis of the sequence reaction products. An almost complete 16S rRNA gene sequence of 1451 nucleotides was determined, and was phylogenetically analysed using the ARB software package (Ludwig et al., 2004). The phylogenetically most closely related species of [Methanogenium] frittonii turned out to be Methanoculleus thermophilus. The 16S rRNA gene sequences of both type strains were almost identical (99.9\% similarity), and had similarity values around $96 \%$ with sequences of other type strains of the genus Methanoculleus, which suggested the affiliation of strain DSM $2832^{\mathrm{T}}$ to this genus. In contrast, [Methanogenium] frittonii was only distantly related to representatives of the genus Methanogenium, as indicated 
by similarity values of below $92 \%$ among $16 \mathrm{~S}$ rRNA gene sequences.

Genomic DNA for the determination of DNA base composition and DNA-DNA hybridization experiments was isolated by using a French pressure cell, and was purified by chromatography on hydroxyapatite, as described by Cashion et al. (1977). DNA-DNA hybridization experiments between both strains were carried out in $2 \times$ SSC buffer containing $5 \%(\mathrm{v} / \mathrm{v})$ formamide at $68{ }^{\circ} \mathrm{C}$, according to the method of De Ley et al. (1970). DNA renaturation rates were measured by using a model Cary 100 Bio UV/VISspectrophotometer equipped with a Peltier-thermostatted $6 \times 6$ multicell changer and a temperature controller with an in situ temperature probe (Varian). The estimated level of DNA-DNA binding between the strains DSM $2832^{\mathrm{T}}$ and DSM $2373^{\mathrm{T}}$ was $86 \%$. According to Wayne et al. (1987), reassociation values above $70 \%$ indicate that the strains belong to the same species.

The affiliation of both strains to one species is supported by several morphological and physiological traits. The sole important physiological difference is the requirement for acetate as a carbon source by Methanoculleus thermophilus, whereas [Methanogenium] frittonii can grow autotrophically. However, Romesser et al. (1979) reported that Methanoculleus marisnigri, a species closely related to Methanoculleus thermophilus, can also grow without acetate as a carbon source. Consequently, within the genus Methanoculleus the requirement for acetate seems to be variable among strains.

A further differentiating characteristic between both type strains is the DNA G+C content. In the original species descriptions of Methanoculleus thermophilus and [Methanogenium] frittonii, $\mathrm{G}+\mathrm{C}$ contents of $59 \mathrm{~mol} \%$ (buoyant density method; Rivard \& Smith, 1982) and $49 \mathrm{~mol} \%$ (buoyant density method; Harris et al., 1984), respectively, were reported. Generally, the variability of $\mathrm{G}+\mathrm{C}$ content among strains within the same species does not exceed 5 mol\% (Rosselló-Mora \& Amann, 2001). To check this discrepancy, we repeated the determination of the DNA $\mathrm{G}+\mathrm{C}$ content of both strains by using reversed-phase HPLC of nucleosides, according to Mesbah et al. (1989). The G $+\mathrm{C}$ content of Methanoculleus thermophilus DSM $2373^{\mathrm{T}}$ and [Methanogenium] frittonii DSM $2832^{\mathrm{T}}$ was found to be $59 \cdot 1$ and $56 \cdot 1 \mathrm{~mol} \%$, respectively. While the reported value for strain DSM $2373^{\mathrm{T}}$ could be confirmed by our results, the obtained value for strain DSM $2832^{\mathrm{T}}$ was inconsistent with the data reported by Harris et al. (1984), but was in good agreement with values obtained by Zabel et al. (1985) and Widdel et al. (1988) by using the thermal denaturation method for three other strains affiliated to the species Methanoculleus thermophilus (55-57 mol\%). Thus, we conclude that the originally reported DNA G + C content of $49 \mathrm{~mol} \%$ for strain DSM $2832^{\mathrm{T}}$ was too low, due to experimental error.

Based on the presented results, it is proposed to unite the species [Methanogenium] frittonii and Methanoculleus
Table 1. Differentiation between the genera Methanogenium and Methanoculleus

Cells of both genera are Gram-negative and have an irregular coccoid shape. Flagella and pili (fimbriae) may be present but motility is rarely observed. Cell envelopes consist of a cytoplasmic membrane and an S-layer of hexagonally arranged glycoprotein subunits with $M_{\mathrm{r}}$ values in the range 101000-138000. $\mathrm{H}_{2}$ and formate can be used by all strains as substrates for methanogenesis. Alcohols may serve as alternative hydrogen donors in some strains. Data from Romesser et al. (1979), Rivard \& Smith (1982), Harris et al. (1984), Zabel et al. (1985), Widdel et al. (1988), Maestrojuán et al. (1990), Franzmann et al. (1997), Zellner et al. (1998), Dianou et al. (2001), Asakawa \& Nagaoka (2003), Chong et al. (2002) and Mikucki et al. (2003). +, Positive in all strains; $\mathrm{d}$, different reaction in different species.

\begin{tabular}{|lcc|}
\hline Characteristic & Methanogenium & Methanoculleus \\
\hline Size $(\mu \mathrm{m})$ & $0 \cdot 5-2 \cdot 6$ & $0 \cdot 6-2 \cdot 0$ \\
$\begin{array}{l}\text { Optimal growth temperature } \\
\left({ }^{\circ} \mathrm{C}\right)\end{array}$ & $15-35$ & $25-60$ \\
Optimal NaCl concentration & $0 \cdot 35-1 \cdot 25$ & $0-0 \cdot 4$ \\
$(\mathrm{M})$ & & $\mathrm{d}$ \\
Requirement for acetate & + & $55-62$ \\
DNA G $+\mathrm{C}$ content $(\mathrm{mol} \%)$ & $47-52$ & \\
\hline
\end{tabular}

thermophilus. According to rules 38,42 and $24 \mathrm{~b}(2)$ of the Bacteriological Code (Lapage et al., 1992), the validly published name Methanoculleus thermophilus has priority and hence should be used for the unified taxon.

In addition, the presented data and a critical review of the relevant literature permit an emendation of the genus Methanogenium, thereby enabling a more distinct differentiation from the related genus Methanoculleus (Table 1).

\section{Emended description of the species Methanoculleus thermophilus (Rivard and Smith, 1982) Maestrojuán et al. 1990}

The characteristics of this species are as described by Rivard \& Smith (1982) and Zabel et al. (1985), with the following exceptions. Secondary alcohols might be used as electron donor by single strains (Widdel et al., 1988). Most strains require acetate as a carbon source for growth, but single strains might be autotrophic. Trypticase peptone or yeast extract stimulates growth in all strains. The DNA $\mathrm{G}+\mathrm{C}$ content is $55-59 \mathrm{~mol} \%$; the type strain has a $\mathrm{G}+\mathrm{C}$ content of $59 \mathrm{~mol} \%$.

The type strain is DSM $2373^{\mathrm{T}}\left(=\mathrm{OCM} 174^{\mathrm{T}}\right)$.

\section{Emended description of the genus Methanogenium Romesser et al. 1981 emend. Maestrojuán et al. 1990}

The description of this genus is that given by Romesser $e t$ al. (1979), emended by Maestrojuán et al. (1990), except that optimal temperatures for growth are between 15 and $35^{\circ} \mathrm{C}$ 
and optimal $\mathrm{NaCl}$ concentrations range from 0.35 to $1 \cdot 25 \mathrm{M}$.

The type species is Methanogenium cariaci.

\section{Acknowledgements}

We are grateful to B. Sträubler and I. Kramer for technical assistance.

\section{References}

Asakawa, S. \& Nagaoka, K. (2003). Methanoculleus bourgensis, Methanoculleus olentangyi and Methanoculleus oldenburgensis are subjective synonyms. Int J Syst Evol Microbiol 53, 1551-1552.

Cashion, P., Holder-Franklin, M. A., McCully, J. \& Franklin, M. (1977). A rapid method for the base ratio determination of bacterial DNA. Anal Biochem 81, 461-466.

Chong, S. C., Liu, Y., Cummins, M., Valentine, D. L. \& Boone, D. R. (2002). Methanogenium marinum sp. nov., a $\mathrm{H}_{2}$-using methanogen from Skan Bay, Alaska, and kinetics of $\mathrm{H}_{2}$ utilization. Antonie van Leeuwenhoek 81, 263-270.

De Ley, J., Cattoir, H. \& Reynaerts, A. (1970). The quantitative measurement of DNA hybridization from renaturation rates. Eur $J$ Biochem 12, 143-153.

Dianou, D., Miyaki, T., Asakawa, S., Morii, H., Nagaoka, K., Oyaizu, H. \& Matsumoto, S. (2001). Methanoculleus chikugoensis sp. nov., a novel methanogenic archaeon isolated from paddy field soil in Japan, and DNA-DNA hybridization among Methanoculleus species. Int J Syst Evol Microbiol 51, 1663-1669.

Franzmann, P. D., Liu, Y., Balkwill, D. L., Aldrich, H. C. Conway de Macario, E. \& Boone, D. R. (1997). Methanogenium frigidum sp. nov., a psychrophilic, $\mathrm{H}_{2}$-using methanogen from Ace Lake, Antarctica. Int J Syst Bacteriol 47, 1068-1072.

Harris, J. E., Pinn, P. A. \& Davis, R. P. (1984). Isolation and characterization of a novel thermophilic, freshwater methanogen. Appl Environ Microbiol 48, 1123-1128.

Lapage, S. P., Sneath, P. H. A., Lessel, E. F., Skerman, V. B. D., Seeliger, H. P. R. \& Clark, W. A. (editors) (1992). International Code of Nomenclature of Bacteria. Bacteriological Code (1990 Revision). Washington, DC: American Society for Microbiology.

Ludwig, W., Strunk, O., Westram, R. \& 29 other authors (2004). ARB: a software environment for sequence data. Nucleic Acids Res 32, 1363-1371.
Maestrojuán, G. M., Boone, D. R., Xun, L., Mah, R. A. \& Zhang, L. (1990). Transfer of Methanogenium bourgense, Methanogenium marisnigri, Methanogenium olentangyi, and Methanogenium thermophilicum to the genus Methanoculleus gen. nov., emendation of Methanoculleus marisnigri and Methanogenium, and description of new strains of Methanoculleus bourgense and Methanoculleus marisnigri. Int J Syst Bacteriol 40, 117-122.

Mesbah, M., Premachandran, U. \& Whitman, W. B. (1989). Precise measurement of the $\mathrm{G}+\mathrm{C}$ content of deoxyribonucleic acid by high-performance liquid chromatography. Int J Syst Bacteriol 39, 159-167.

Mikucki, J. A., Liu, Y., Delwichi, M., Colwell, F. S. \& Boone, D. (2003). Isolation of a methanogen from deep marine sediments that contain methane hydrates, and description of Methanoculleus submarinus sp. nov. Appl Environ Microbiol 69, 3311-3316.

Rainey, F. A., Ward-Rainey, N., Kroppenstedt, R. M. \& Stackebrandt, E. (1996). The genus Nocardiopsis represents a phylogenetically coherent taxon and distinct actinomycete lineage: proposal of Nocardiopsaceae fam. nov. Int J Syst Bacteriol 46, 1088-1092.

Rivard, C. J. \& Smith, P. H. (1982). Isolation and characterization of a thermophilic marine methanogenic bacterium, Methanogenium thermophilicum sp. nov. Int J Syst Bacteriol 32, 430-436.

Romesser, J. A., Wolfe, R. S., Mayer, F., Spiess, E. \& WaltherMauruschat, A. (1979). Methanogenium, a new genus of marine methanogenic bacteria, and characterization of Methanogenium cariaci sp. nov. and Methanogenium marisnigri sp. nov. Arch Microbiol 121, 147-153.

Rosselló-Mora, R. \& Amann, R. (2001). The species concept for prokaryotes. FEMS Microbiol Rev 25, 39-67.

Wayne, L. G., Brenner, D. J., Colwell, R. R. \& 9 other authors (1987). Report of the ad hoc committee on reconciliation of approaches to bacterial systematics. Int J Syst Bacteriol 37, 463-464.

Widdel, F., Rouviere, P. E. \& Wolfe, R. S. (1988). Classification of secondary alcohol-utilizing methanogens including a new thermophilic isolate. Arch Microbiol 150, 477-481.

Zabel, H.-P., König, H. \& Winter, J. (1985). Emended description of Methanogenium thermophilicum, Rivard and Smith, and assignment of new isolates to this species. Syst Appl Microbiol 6, 72-78.

Zellner, G., Messner, P., Winter, J. \& Stackebrandt, E. (1998). Methanoculleus palmolei sp. nov., an irregularly coccoid methanogen from an anaerobic digester treating wastewater of a palm oil plant in North-Sumatra, Indonesia. Int J Syst Bacteriol 48, 1111-1117. 